\title{
Correction to: Art as an Instrument of Philosophy
}

\author{
Helen Petrovsky
}

\section{CORRECTION TO:}

Chapter 35 in: M. F. Bykova et al. (eds.), The Palgrave Handbook of Russian Thought, https://doi.org/10.1007/978-3-030-62982-3_35

An older version of the abstract has been published online erroneously which is corrected now and given below.

The chapter focuses on two distinct tendencies in contemporary Russian thought regarding its approach to art. The first is exemplified in the original method developed by the philosopher Valery Podoroga, namely, his analytical anthropology of literature and art. Offering a fresh reading of the Russian formalists as well as of phenomenology, Podoroga develops his own conception of mimesis and what he terms as "Work." The second trend has to do with the understanding of art as a phenomenon of mass societies. This approach emphasizes collective affectivity and is associated with the work of Oleg Aronson and the ideas of the composer Vladimir Martynov. Here art is no longer the object of reflection, but a new ground for thinking itself. The same perspective is shared by younger scholars, such as Alexandra Volodina and Denis Larionov, who explore the various manifestations of "minor" art.

The updated version of this chapter can be found at https://doi.org/10.1007/978-3-030-62982-3_35

(C) The Author(s), under exclusive license to Springer Nature 